\title{
The Rank Prize Funds: Nurturing Advancement in Optoelectronics \\ Carol Trager-Cowan
}

The classic British films of Brief Encounter (1945), Great Expectations (1946), The Red Shoes (1948), and The Thirty-Nine Steps (1959), produced by The Rank Organisation, may be well known but few viewers may be aware of the role that The Rank Prize Funds play in recognizing excellence and nurturing progress in the field of optoelectronics.

The Rank Organisation and The Rank Prize Funds both owe their existence to J. Arthur Rank, later to become Lord Rank (1957). He was born in 1888 into a wealthy flour-milling family and at the age of 17 he joined the family business.

Lord Rank was a devout Christian and taught at the Sunday School of his local church. He liked to show the children religious films, but was unhappy with the quality of what was available and so decided to produce his own. From 1934, filmmaking and later film distribution and exhibiting were to become a major part of his life. He created the Rank Organisation in 1937 which was to own Pinewood Film Studios, Denham Film Studios, Ealing Studios, Lime Grove Studios, and Islington Studios as well as the Odeon Cinema chain. By 1941 he dominated the British cinema industry.

Lord Rank and his wife Lady Rank were great philanthropists who undertook a wide range of charitable work; in 1953 they set up the J. Arthur Rank Group Charity (now The Rank Foundation). Today, The Rank Foundation supports activities which encourage and develop leadership among young people, activities which support disadvantaged young people and those frail or lonely through old age or disability and activities which promote Christian principles through film and other media. For example, the Rank Foundation has provided funding toward a drop-in center for the homeless; provides funding to support young people as volunteers and leaders in the community; supports an educational facility for families, schools, respite centers, play schemes, and clubs, all of whom care for children with disabilities or specific needs (www. rankfoundation.com).

Donations were made from The Rank Foundation to endow The Rank Prize Funds. The Rank Prize Funds, as noted in the mission statement, "were established by Lord Rank on the 16th February 1972, shortly before his death in March of that year. There are two Funds, the Nutrition Fund and the Optoelectronics Fund, encompassing the two sciences that reflect the business interests of the late Lord Rank through his connection with the flour-milling and cinema and electronics industries." These areas were also of interest to Lord Rank because he believed they would be of special benefit to humanity. The funds are ably administered by the Trustees and an Advisory Committee for "Human and animal nutrition and crop husbandry" and an Advisory Committee for "Optoelectronics." The two Advisory Committees comprise distinguished scientists who give their time freely to the work of The Rank Prize Funds (www.rankprize. org/Committees.htm).

The Rank Prize Funds recognize and foster excellence in the optoelectronics area through a wide range of innovative activities. For example, they provide studentships to enable undergraduates to undertake research during the summer vacation, they have developed electronics kits for schools, and are presently creating an Optoelectronics College to support and equip teachers to enthuse 13-14-year-old students with curriculum-relevant optoelectronic resources. Activities will explore how objects such as liquid-crystal displays, light-emitting diodes, and solar cells work.

The Rank Prize Funds also supports, encourages, and rewards researchers working at the cutting edge of optoelectronics research. By the award of annual prizes, the trustees of The Funds "seek to identify those individuals who have made a significant contribution ..., where an initial idea has been carried through to practical applications that have, or will, demonstrably benefit mankind" (www.rankprize.org). For example, in 2008, Professor P.B. Denyer and colleagues Dr. D. Renshaw, Dr. M. Lu, and Professor G. Wang from the University of Edinburgh were awarded prizes "for their work on the first CMOS [complementary metal oxide semiconductor] image sensors for digital cameras." Professor M.V. Srinivasan of The Australian National University was awarded a prize "for his work on insect vision and its application to robotics." The 1998 prize "for contributions to the invention of nitride-based blue and green semiconductor diode lasers" spanned two continents being awarded to Professor S. Nakamura of the University of California, Santa Barbara, Professor I. Akasaki of Meijo and Nagoya Universities, Professor H. Amano of Meijo University, and Professor J.I. Pankove of Astralux, Inc., Boulder, Colorado.

The Advisory Committee also organize regular meetings (typically four a year) which they term "mini-symposia." A mini-symposium brings together about 10 leading scientists and 20 younger researchers, who over two and a half days, give and listen to short presentations and take part in animated discussions in comfortable and informal surroundings. "It is hoped that by creating such a forum the younger scientists will be encouraged to explore and develop their skills and make contacts that will help them push forward the frontiers of their science" (www.rankprize.org/Symposia.htm). Some recent mini-symposia included Optoelectronics for Use in the Diagnosis of Cancer (2005); Metamaterials in Nature and Technology (2006); Still and Moving Images: From Signals to Semantics (2007); and in 2008 (which the author was privileged to attend), Physics and Applications of InN and InGaN Semiconductor Materials.

The mini-symposia are meetings with a difference-most are held in the beautiful surroundings of the English Lake District-emphasis is placed on 
discussion and the imparting of knowledge to the younger scientists. Discussion is encouraged by timetabling discussion sessions into the program. Excellent food and the free bar to midnight all encourage discourse, and impromptu tutorials run long into the night. There is a strong international element to the mini-symposia. At the Physics and Applications of $\mathrm{InN}$ and InGaN Semiconductor Materials MiniSymposium we had both leading scientists and younger scientists from Germany, Spain, and the United States as well as from the United Kingdom, so there was a cultural exchange in addition to the scientific exchange between the participants. In the course of the symposium we were treated to a thorough overview of the current state-of-the-art growth, characterization, and theoretical modeling of $\mathrm{InN}$ and InGaN semiconductors, allowing the younger scientists to see where their research fit into our understanding and exploitation of these materials.

\section{The Rank Prize Funds} recognize and foster excellence in the optoelectronics area through a wide range of innovative activities.

Another unique element of The Rank Prize mini-symposia is the traditional hike up one of the nearby hills. Before the evening meal on the first day of the symposium, delegates don their walking shoes and go out into the fresh air to enjoy beautiful views over the Lake District. Reaching the top of the hill is rewarded by a glass of orange juice and champagne. The hardest thing about The Rank Prize mini-symposia is telling students that the beautiful accommodation, the "haute cuisine," the free bar, the champagne, and the focus on students and on discussion are quite unique.

Lord Rank has left an amazing legacy to science and to the human race. The many diverse activities run by The Rank Prize Funds, from the resources to schools, to the inspirational activities run to support and encourage young scientists, to the prizes for cutting-edge research, provide motivation and inspiration to this and the next generation of scientists whose science is of benefit to humanity.

Carol Trager-Cowan has been a senior lecturer in the Physics Department at the University of Strathclyde in Glasgow since 1998.
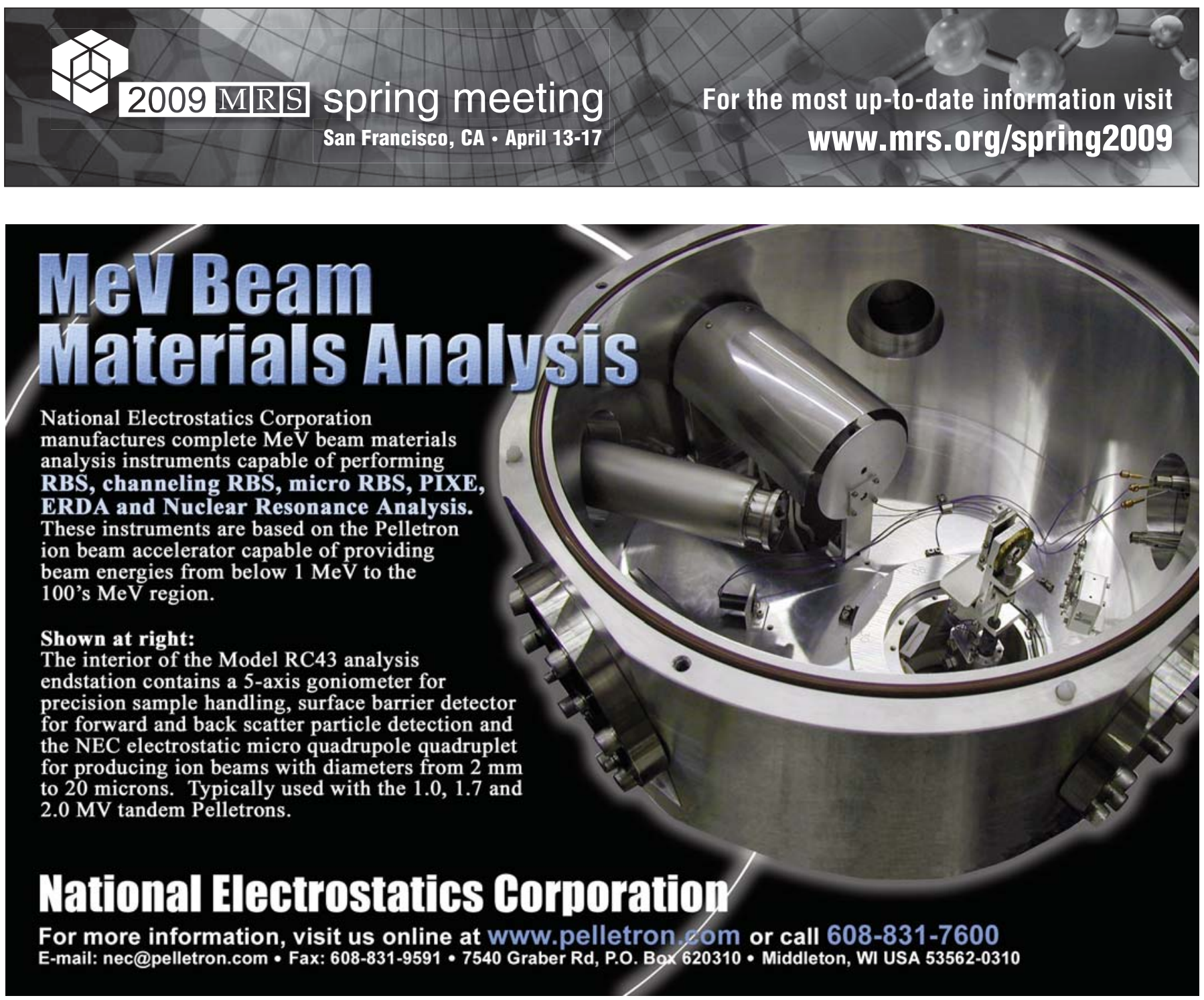